\title{
Inclusive Excellence and Underrepresentation of Students of Color in Study Abroad
}

\author{
Karyn Sweeney \\ Doctoral student, University of Denver
}

During the 2010/11 academic year, 273,996 U.S. college and university level students opted to study abroad for academic credit (Institute of International Education, 2012). U.S. colleges and universities increasingly look to study abroad and other internationalization efforts as tools to prepare students to engage successfully in a global work environment (Stearns, 2008). However, not all college students participate in study abroad at equal rates. The typical participant is White, female, middle to upper middle class, and majoring in the humanities, social sciences, or business (Picard, Bernardino, \& Ehigiator, 2009).

As illustrated in Table 1, students of color are underrepresented in study abroad participation. The percentage distribution of African American students enrolled in U.S. higher educational institutions increased from $12.7 \%$ in 2005 to $14.5 \%$ in 2010 , but the rate of study abroad participation grew at a slower rate, from $3.5 \%$ in the $2005 / 06$ academic year to $4.8 \%$ in the $2010 / 11$ academic year. The Latino/a student population increased from $10.8 \%$ to $13 \%$ during this period, while study abroad participation grew from $5.4 \%$ in $2005 / 06$ to $6.9 \%$ in $2010 / 11$. American Indian/Alaska Native students have seen little change in overall enrollment in institutions of higher education or in study abroad participation. During this era Asian/Pacific Islander students participated in study abroad in relative proportion to their overall enrollment in higher education, and since 2008/09 have even participated in study abroad at a higher rate $(7.9 \%)$ than their proportional enrollment in higher education (6\%). The Asian/Pacific Islander category includes many ethnic sub-groups, however, and both study abroad participation and academic achievement varies considerably among these sub-groups (Doan, 2002; Van Der Meid, 2003).

White students are overrepresented in study abroad participation, constituting 60.5\% (2010) of the total population of students in U.S. post-secondary institutions and $77.8 \%(2010 / 11)$ of the study abroad population (Institute of International Education, 2012; National Center for Education Statistics, 2011). There have been only small changes in the proportion of students of color who participate in study abroad over the past decade, and these small increases are likely a product of increasing numbers of students of color enrolled in U.S. higher educational institutions rather than a direct result of efforts to counteract the underrepresentation of students of color in study abroad (Stallman, Woodruff, Kasravi, \& Comp, 2010).

With increased institutional and national emphasis on both the importance of study abroad and the need for diversification of participants, it is critical that the study abroad participation of students of color and other underrepresented students be more closely examined to learn if and how their pathways to study abroad and experiences differ from those of the more typical (and overrepresented) participant, a White woman. The NAFSA Guide to Education Abroad for Advisors and Administrators identifies a "clear need to examine policies and practices that are discriminatory 
and exclusionary, however unintended, as a part of the collective experience in education abroad" (Lebold, Henry, Houston, Jackson, Scheibe, \& Van Der Meid, 2005, p. 212).

The concept of inclusive excellence and the inclusive excellence scorecard are tools that can be utilized by international educators to examine the participation of students of color in study abroad within our own institutions and organizations, to evaluate efforts to resolve underrepresentation, and to inform best practices to support learning and development for all students throughout the study abroad process. While the scorecard as described here has been modified to examine the participation of students of color, it can be adapted for other underrepresented groups within study abroad.

Inclusive excellence shifts diversity efforts from a simple focus on numbers and individual efforts to a comprehensive examination of the entire university system and the ways in which it recognizes, enhances, and facilitates the contributions of all community members (Milem, Chang, \& Antonio, 2005). As defined by the Association of American Colleges and Universities, inclusive excellence incorporates four elements:

1. A focus on student intellectual and social development.

2. A purposeful development and utilization of organizational resources to enhance student learning.

3. Attention to the cultural differences that learners bring to the educational experience and that enhance the enterprise.

4. A welcoming community that engages all of its diversity in the service of student and organizational learning (Milem et al., 2005, p. vi).

Williams, Berger, and McClendon (2005) developed a scorecard to assess inclusive excellence efforts and inspire institutional change. The four areas of examination include access and equity, campus climate, diversity in the formal and informal curriculum, and learning and development. Adapted for study abroad, access and equity addresses the numbers of underrepresented students who participate in study abroad as well as levels of success. Campus climate focuses on the "development of a psychological and behavioral climate supportive of all students" (Williams et al., 2005, p. 21), both on the home campus and in the study abroad setting. Diversity in the formal and informal curriculum examines the inclusion of content addressing diversity across the study abroad experience, including advising materials, orientation and other programs, courses, and social experiences. This category also includes the type of study abroad programs offered. Student learning and development gives attention to knowledge acquisition regarding diverse groups and cultures as well as cognitive and social development (Williams et al., 2005). Additionally, the student learning and development category can incorporate racial and ethnic identity development, the development of a national identity, and connections between the study abroad experience and academic major(s) and minor(s).

Williams et al. (2005) note that many institutions concentrate on compositional diversity and fail to take a more comprehensive approach to inclusive excellence. Existing research within study abroad as well as discussions within the professional field tends to relate to the access and equity and campus climate areas of the scorecard, as it appears that international educators also tend to focus on 
the numbers of diverse student participants rather than a thorough examination of the entire study abroad process and students' experiences. Williams et al. (2005) offer definitions and sample indicators for each inclusive excellence area. In the following pages, definitions and indicators for all four inclusive excellence scorecard areas are developed with a specific focus on study abroad.

\section{Access and Equity}

The access and equity category in the inclusive excellence framework addresses compositional diversity and levels of success in study abroad.

Most students of color are underrepresented in terms of participation. What factors impede access to study abroad opportunities? Comp's content analysis of literature related to students of color and study abroad (both anecdotal and empirical) found the most commonly cited factors for non-participation included finances, lack of family support, and a lack of program sites of interest to students of color (2007). While the barriers identified anecdotally are often confirmed by the limited research in this area, empirical works frequently illustrate that these barriers are far more complicated and nuanced than previously considered. In addition, discussions of barriers to study abroad tend to focus on student characteristics. Overcoming inequities requires a consideration of deficits at the institutional level (Bauman, Bustillos, Bensimon, Brown II, \& Bartee, 2005). While individual circumstances may impact participation, institutions must closely examine their practices and procedures to determine if and how they contribute to underrepresentation in study abroad.

The expense of study abroad is one of the most often cited barriers to study abroad participation, not only for some students of color, but for all students with limited financial means. Several works have included an examination of the impact, both perceived and real, financial concerns have on the decision whether or not to study abroad. A study focused on community colleges found that faculty, staff, and administrators believed that the inability to afford study abroad was one of the major barriers to participation; students at these same institutions indicated that while cost was important, 70\% felt that cost alone would not be enough to prevent them from study abroad (Raby, 2006). Kasravi found that affording study abroad was a barrier for both students who opted to study abroad and those who did not (2009). Students who studied abroad overcame the financial barriers through various means, including choosing a shorter (and less expensive) program, opting for a more affordable destination, applying for scholarships, working more, and moving home to save money (Kasravi, 2009).

Jackson (2005) asserts that media influences and historical exclusion from study abroad has led to what she calls the "not for people like me" syndrome for students of color, resulting in little interest in study abroad. First Lady Michelle Obama echoed this sentiment in her recent speech at Howard University:

I grew up in a blue-collar neighborhood on the south side of Chicago, and the idea of spending time abroad just never registered with me. My brother and I were among the first in our families to go to college. So, trust me, we were way more focused on getting in, getting through, and getting out, than we were with finding opportunities that would broaden our horizons (Obama, 2011). 
While the argument that students of color are not interested in study abroad appears in nonempirical literature, some recent studies contradict this assumption. An examination of factors impacting the choice to study abroad in 2,772 first year students attending 19 institutions found no statistical difference between African American and White or Latino/a and White students in regards to the intent to study abroad (Salisbury, Umbach, Paulsen, \& Pascarella, 2009). Penn and Tanner's (2008) survey of 41 African American high school graduates in a summer pre-college program found that $83 \%$ indicated interest in a study abroad experience, which "chips away at the belief found in much of the previous literature that Black students have no desire or information about international education programs" (p. 278).

In an examination of measures of capital that influence students' intent to study abroad, Salisbury, Paulsen, \& Pascarella found differences between racial and ethnic groups (2011). For example, an increase in the openness to diversity and challenge scale increased the likelihood of study abroad intent for white students, but did not have an effect in African-American or Asian-American students, perhaps because many students of color are already skilled at navigating multicultural environments in the U.S. (Salisbury et al., 2011). Aspirations for a graduate degree increased the likelihood of study abroad intent among African American and Asian American students, but decreased the likelihood among White students (Salisbury et al., 2011). The authors note:

Although study abroad is often marketed as if all students should be attracted to study abroad for the same reasons, these findings suggest that some of the most widely used arguments in favor of participation — that study abroad will provide opportunities for cross cultural skill development and improve post-graduate career opportunities-appear to have no affect on increasing study abroad intent among most minority students (Salisbury et al., 2011).

While there is much discussion of the numbers of students of color who study abroad and potential barriers that prevent students from accessing these experiences, there is little research specifically addressing success in study abroad by students of color. This may be due to the overall lack of research focused on assessment and learning outcomes. A push for assessment in study abroad has occurred in recent years; the Forum on Education Abroad issued A Guide to Outcomes Assessment in Study Abroad, and has indicated assessment as one of the most important topics for the profession (Bolen, 2007). Though assessment is increasingly a topic of discussion among international educators and emphasized in professional conferences, many working in education abroad are still struggling to determine what to assess and how to conduct assessment. As these efforts move forward, institutions and researchers must examine this data to see if racial and ethnic differences exist.

Although few studies have specifically addressed study abroad outcomes for students of color, Sutton and Rubin's (n.d.) examination of study abroad in the University System of Georgia found that study abroad did have an influence on overall academic success. African American study abroad participants were 30\% more likely to graduate in four years than African Americans who did not study abroad. Four-year graduation rates for other students of color who studied abroad were 18\% higher than those of their peers who did not study abroad (Redden, 2010). Study abroad had a 
smaller impact on graduation rates of White study abroad participants, who were $12 \%$ more likely to graduate in four years (Sutton \& Rubin, n.d.).

\section{Inclusive Excellence Scorecard: Indicators for Access and Equity}

To move towards creating an inclusive campus, it is crucial that institutions collect and examine data rather than assume that problems are known and understood (Bauman, Bustillos, Bensimon, Brown II, \& Bartee, 2005). While finances, family, and culture are widely assumed to influence the ability of students of color to study abroad, the saliency of these factors will vary according to student and institution, and are unlikely to be the only barriers to study abroad participation. Efforts to increase the participation in study abroad by students of color must begin with institutional selfassessments. Institutional contexts as well as students vary, so it cannot be assumed that what works at one institution will have the same effect in another (Kuh, 2009). In collecting and interpreting this data, collaboration with others on campus is also important, as "not all of the issues facing underrepresented constituencies are obvious and visible to the education abroad professional" (Lebold, Henry, Houston, Jackson, Scheibe, \& Van Der Meid, 2005, p. 210). Offices of institutional research, admissions, multicultural services, and student affairs may be able to assist in providing a profile of students of color at the institution (Picard, Bernardino, \& Ehigiator, 2009).

There are a number of scorecard indicators that may be used by institutions to examine access and equity in study abroad (see Table 2). These indicators can be divided into two broad categories: those that measure access, and those that measure equity, or student success. First, institutions need to determine who is and is not studying abroad. The race and ethnicity of study abroad applicants can be compared to the overall student population to determine whether students of color are equally represented in terms of participation, and if there are differences in participation rates among various groups. The majors of study abroad participants should also be considered. Are there particular majors that are more likely to study abroad? Are students of color over- or underrepresented in these majors? Surveys of prospective participants or of applicants can also be a rich source of information. Study abroad offices can ask students how they learned about study abroad opportunities, and determine whether these preferred sources of information vary by race and ethnicity. This information can assist in future outreach efforts.

It is also crucial to speak with students of color directly about their involvement- or lack thereof - with study abroad opportunities. Harper and Quaye (2009) advise that educators must listen to students, as any strategies intended to improve engagement must be based on the students' own experiences and backgrounds. Study abroad staff members will likely have access to students of color who have studied abroad, who should be asked about why they chose to study abroad, their goals, and successes and challenges during the process. It may be more difficult to connect with students of color who have opted not to study abroad, but other faculty and staff on campus may be able to assist in identifying focus group participants. Surveys are another source of data; these may be surveys specifically focused on study abroad, or institutions may incorporate questions about study abroad into existing student surveys (of all graduating seniors or alumni, for example).

In addition to determining who is and is not opting to study abroad, equity, or levels of success, should be examined. How many students withdraw from study abroad after application, or return 
from the study abroad program before it has ended? What are their reasons for doing so? Has the race/ethnicity of these students been examined? Students who study abroad and have a positive experience may decide to extend their program or to study abroad a second time. Has the race/ethnicity of these students been considered to see if students of color are equally represented among these students? How does GPA during the study abroad program vary by race/ethnicity? What is the impact of study abroad on graduation rates and on post-study abroad GPA, and do these results vary by race/ethnicity?

Discussions regarding access to study abroad by students of color must move beyond assumptions of barriers. Examining who has access to study abroad and why, though only the first step in impacting underrepresentation, is crucial in order to effect change. In addition, institutions should examine the success levels of all students who do study abroad to determine if there are patterns of inequity.

\section{Campus Climate}

Campus climate focuses on the "development of a psychological and behavioral climate supportive of all students" (Williams et al., 2005, p. 21) both on the home campus and in the study abroad setting. Institutions must examine whether their policies, procedures, and communications are impacting lack of participation in study abroad by students of color. Though individual circumstances are often blamed for underrepresentation of students of color in study abroad, Carter (1991) argued that campus culture and lack of faculty and administrative support are the major impediments to study abroad for African American students. Faculty and staff assume that African Americans are not qualified to study abroad or are not interested, so do not work to actively recruit these students (Carter, 1991). Faculty and staff may not feel that study abroad is essential for any student, much less for students who already face challenges in higher educational institutions. Norfles (2003) surveyed 245 staff of Federal TRIO programs ${ }^{1}$ and discovered that many of the staff and directors did not value study abroad as important for their students, but rather considered it to be an unnecessary luxury.

Several studies have suggested that the obstacles identified by faculty, staff, and administrators may differ from those identified by students (Carter, 1991; Norfles, 2003; Raby, 2006). A study in collaboration with California Colleges for International Education (CCIE) found that California community college system administrators, faculty, and staff attributed lack of participation in study abroad to finances, family/work obligations, and lack of cultural capital (Raby, 2006). Students in these same community colleges, meanwhile, cited lack of college infrastructure, a shortage of study abroad offerings, and lack of knowledge about existing programs as the primary barriers to their participation in study abroad (Raby, 2006). Kasravi found that most of her research participants heard about study abroad through the study abroad office, not from an advisor or professors (2009).

\footnotetext{
${ }^{1}$ Federal TRIO programs provide outreach and support services for students who are low-income, first generation college students, and students with disabilities. The goal is to increase access to post-secondary education opportunities (U.S. Department of Education, 2011).
} 
If faculty, staff, and administrators have already decided that students of color are not able or willing to go abroad, they may not encourage them to do so. Institutions may be able to increase participation rates of students of color through careful attention to policies and campus initiatives (Bailey Shea, 2009). Bailey Shea utilized national data sets to examine predictors of study abroad participation, and discovered that, "White students were more likely to arrive at college with factors that predisposed them to participate, whereas the factors that influenced minority student participation were more affected by experiences and choices students made while in college" (2009, p. 177).

For those students who do choose to study abroad, the climate at the host university and/or in the host community may also have an impact both on the student abroad and future participants. If students of color have a negative study abroad experience, they could be hesitant to recommend the experience to their peers.

An African American student who published a guide for other study abroad participants describes her experience in Buenos Aires, Argentina:

I began to realize the stares were because of my skin color, not my nationality. I was a black woman in Argentina, a country with people of mostly European descent. Anywhere I went I stuck out like a sore thumb... No one could believe that I was American... One thing stuck with me that I just could not ignore, why hadn't anyone told me about this before I left? (Lewis, 2009, p. 51)

Limited research has suggested that race and ethnicity and fears of discrimination may impact a student's ability and willingness to interact with the host culture, which may in turn impact learning outcomes (Talburt and Stewart, 1999). In contrast, several of Jackson's participants expressed that they did not anticipate racism abroad would be greater or different than what they experienced in the U.S. - they were more concerned by anti-Americanism (2006). One student noted that her experiences in the U.S. negotiating between cultures had helped her develop flexibility and prepared her for cultural adaptation abroad (Jackson, 2006).

The ways in which students of color perceive the climate in their host countries is likely to be influenced by their lived experiences with racism in the U.S. Providing opportunities for students to discuss the climate in their host countries, both prior to departure and while in-country, may help them to develop both coping strategies and realistic expectations. This is not to suggest that all students of color experience discrimination while abroad; experiences will vary considerably from student to student and from country to country. Students of color may find a more welcoming climate abroad than at their home institutions. While Talburt and Stewart (1999) found that race could negatively impact cultural adjustment, Jackson (2006) suggests that experience negotiating cultural differences in the U.S. may mean that students of color are better able to adapt to their host country. Jackson's participants shared that "dealing with the attitudes of their White compatriots was often more challenging than dealing with the host country nationals" (2006, p. 177). More research is needed, and it is crucial for institutions to examine the experiences of their own students of color, both on the home campus and abroad, to better understand students' challenges and opportunities and the type of support needed. 


\section{Inclusive Excellence Scorecard: Indicators for Campus Climate}

Both climates at home and abroad may impact the experiences of students of color. To evaluate campus climate at the home institution as well as on the study abroad program, institutions can work with other offices on campus to gather data and consider the indicators outlined in Table 3 .

A number of these indicators address compositional diversity, both on the home campus and abroad. Compositional diversity can be seen as a symbol of an institution's commitment to diversity (Milem, Chang, \& Antonio, 2005; Hurtado, 2002). Institutions should examine the race and ethnicity of staff in the education abroad office, as well as that of faculty from the home campus who lead study abroad programs. Although no studies appear to have examined the relationship between compositional diversity and study abroad participation by students of color, the presence of faculty of color has been shown to be a predictor of African American enrollment in graduate programs and of graduation rates (Allen, Epps, Guillory, Suh, Bounous-Hammarth, \& Stassen, 2002). Picard et al. (2009) ask whether it is more important to have staff of color or empathetic staff in the study abroad office, given the underrepresentation of persons of color in the international education profession. While faculty and staff of color play a crucial role in students' perceptions of a welcoming campus climate, they may feel obligated to serve as mentors for students of color and experience fatigue (Allen et al., 2002). In an examination of faculty teaching on U.S. campuses, faculty of color reported that they were often labeled the expert on diversity issues, which their colleagues used as an excuse to avoid dealing with race (Chesler, Lewis, \& Crowfoot, 2005). The presence of faculty and staff of color at the host institution abroad may assist in making students of color feel comfortable, but if these individuals are from a country and culture different from that of U.S. students, they may not have an understanding of the racial history and climate experienced by U.S. students of color. Compositional diversity is important, but not enough to create a positive climate. It is essential to recognize that all faculty and staff involved with international education (and on U.S. campuses) have the responsibility to support students of color, and should be offered professional development opportunities related to diversity and inclusive excellence.

Hurtado (2002) found that increasing the enrollment of Hispanic students on U.S. campuses created the perception that they were welcome. Do students of color see themselves reflected in study abroad marketing and pre-departure materials? Growing numbers of study abroad offices hire study abroad returnees in peer advisor positions; these peers are often the first point of contact for students interested in study abroad opportunities (Anderson \& Murray, 2005). Purposefully hiring peer advisors who are students of color can not only help other students of color see themselves as study abroad participants, but can also contribute to a pipeline towards professional employment in the education abroad field for these returnees.

Another aspect of climate that can be examined is the institution's overall support for study abroad opportunities as well as encouragement for all students' access to these programs. Does study abroad appear in the institution's mission statement? Does the study abroad office's mission statement mention diversity and encourage all students to participate? Do faculty, staff, and 
administrators believe that study abroad is valuable, and do they encourage all students to participate?

Institutions should be encouraged to research campus climate issues at home to learn more about the situation faced by their students of color. If the university has recently conducted a campus climate survey, the study abroad office can review findings to learn what challenges and obstacles students face on the home campus. Not only will this assist in better understanding the experiences of students of color, but the study abroad office can also use results to identify and address areas in which they themselves may be contributing to a negative campus climate.

It is also crucial to learn more about what students of color experience while abroad, both in terms of discrimination and supportive environments. Though each person's study abroad experience is unique, the education abroad office can look for patterns that may occur in certain programs and/or countries. All students can be asked about experiences related to racial and ethnic identities in post study abroad surveys, which are typically anonymous or confidential. Students can also be encouraged to share this information directly with staff in order to improve advising for future participants. Students may also respond to requests to take part in information sessions for peers interested in study abroad, or to speak one on one with prospective participants. If the study abroad office has close relationships with other offices on campus, they may also be able to glean information about challenges faced abroad from other faculty and staff who work closely with students of color. When conducting site visits and program evaluations, the climate for students of color can be considered. Once institutions are aware of what types of climate issues students of color face abroad, they can work with both the students and on-site staff to develop strategies to address problems. Since U.S. universities struggle with their own climate issues, it is naïve to believe that study abroad offices will be able to remove all challenges related to race and ethnicity experienced in the host country. They can, however, let partner programs and host institutions know that they have high expectations that their students of color will be valued and supported. Staff can also work with returnees and future participants to create formal or informal mentoring programs so that returnees can advise participants on strategies to deal with racism and race-related challenges abroad, as well as share the positive aspects of being a student of color abroad.

\section{Diversity in the Informal and Formal Curriculum}

Diversity in the formal and informal curriculum addresses the inclusion of content related to diversity throughout the study abroad experience, including advising materials, orientation and other pre-departure and preparation programs, academic courses, social experiences, and reentry programming. This inclusive excellence area also examines the type of study abroad programs offered.

Despite the lack of research regarding diversity in the informal curriculum, incorporating diverse content into marketing materials, orientations, and programs is often suggested as a means to better attract and support students of color (Carter, 1991; Cole, 1991; Ganz, 1991; Kasravi, 2009; McClure, Szelenyi, Niehaus, Anderson, \& Reed, 2010; Picard, Bernardino, \& Ehigiator, 2009; Tilman, 2010). In addition, the historical participation of people of color in international academic pursuits can also be emphasized. Although White students are overrepresented in study abroad, in 
actuality some communities of color have a long history of international study and travel that can and should be presented to students. Evans (2009) highlights the international academic history of African Americans beginning in the $19^{\text {th }}$ century, focusing on the experience of Anna Julia Cooper, who earned a Ph.D. at the Sorbonne in Paris in 1925 at the age of 66. A number of African Americans chose to earn degrees or conduct research outside the U.S., seeking a more supportive academic environment (Evans, 2009). Evans seeks to illustrate the international academic history of African Americans, noting that "the history of black women's study abroad can assist in moving barriers to educational opportunities that still exist for many black and women students" (2009, p. 94). Rather than assuming that communities of color have always been excluded from study abroad, international educators should explore whether in fact this is true, and share this knowledge with students.

The types of study abroad programs available may impact participation by students of color, who may be discouraged by their largely Eurocentric focus (McClure, Szelenyi, Niehaus, Anderson, $\&$ Reed, 2010). Goodwin and Nacht propose that although study abroad is useful to all students, "since the current structure is largely the creation of upper-middle-class white Americans of western European extraction, it is unattractive to minorities" (1988, p. 76). Non-traditional locations can be beneficial for all students: "the historical persistence of the traditional focus on Western Europe, in the eyes of many experts, has severely curtailed the capacity of study abroad to prepare students, and by extension the nation itself, for the global focus and realities that will shape life in this century" (Hoffa \& DePaul, 2010, p. 2)

Several studies found that both Asian/Pacific Islander and Latino/a students may be interested in heritage-seeking when choosing a study abroad destination (Doan, 2002; Guerrero, 2006; McClure et al., 2010; Van Der Meid, 2003). Landau and Moore discovered that African American students studying abroad in Ghana were motivated by a quest for personal history and roots (2001). One participant noted: "A Black man going to Africa, you just have to see it for yourself...Black people, Black presidents, and Black people in all sorts of power. Black people as the majority, you are no longer the minority. It's amazing, and I wanted to witness it for myself' (Landau \& Moore, 2001, p. 33). While McClure et al. (2010) suggest that more programs should be developed in countries populated by persons of color, students on these programs may also face unexpected challenges. Students might expect to fit in and be embraced, but this does not always occur (Comp, 2008; Jefferson, 1997; Landau \& Moore, 2001). The climate abroad may have unanticipated consequences on students even in a country primarily populated by persons of color. Climate, curriculum, and learning and development are all interconnected, and may in turn impact access. The inclusion of formal and informal discussions of race and ethnicity, as well as culture and history, can encourage students to reflect on their identities as well as cultural and historical differences. Talburt and Stewart recommend that:

The different linguistic lessons and coping strategies that students learn from how members of the host culture perceive and treat them - the lessons of the raced and gendered nature of study abroad - should form an integral part of the formal on-site curriculum. Not only will this inclusion enable students marked by their race and gender to understand and deal with their positions, but it will invite all students to use race and gender as a fulcrum for cultural 
understanding (1999, p. 173).

Landau \& Moore found that "American students, both black and white, are forced to examine their domestic racial codes abroad. In fact, some whites noted they were forced to deal with "race in America" for the first time in Ghana" (Landau \& Moore, 2001, p. 47). This examination of race and racism would likely be more productive if structured and facilitated as part of the program, and in turn has the potential to effect student learning and development.

\section{Inclusive Excellence Scorecard: Indicators for Diversity in the Curriculum}

An attention to diversity in the informal curriculum of study abroad, such as advising materials, orientations, and social programs, may offer better support and encouragement to students of color as they prepare for the study abroad experience. Inclusion of diversity content in the formal curriculum of study abroad coursework may provide powerful opportunities for all students to reflect upon their identities, race in the U.S. and abroad, and position as "other." For a list of potential indicators related to diversity in the curriculum, see Table 4.

To evaluate diversity in the study abroad curriculum, institutions can examine whether race and ethnicity are addressed in advising materials for prospective students and in pre-departure and onsite orientation programs and materials. The potential impact of study abroad on identity development and the impact of identities on the study abroad experience and how students are perceived in-country are valuable conversations to have with all students preparing to study abroad. On-site orientations can include more specific discussions about race and ethnicity in the host country. What are the demographics of the host country? What roles have communities of color played in the country's culture and history? What resources exist for U.S. students of color? Courses offered on site can also be evaluated. Are courses focusing on race and ethnicity in the host country offered? In other courses, are the contributions of persons of color in the field of study included?

When institutions select or develop study abroad programs, the academic offerings, housing, support services, costs, and location are often considerations (Johnson, Rinehart, \& Van Cleve, 2005). While these features are essential, institutions should also evaluate whether the programs offered are of interest to the students of color at their institutions. Do available programs fit the needs of all students on campus in terms of location, academic content, program length, and cost? What are the goals of students of color on the home campus in terms of study abroad participation, and do existing programs fulfill their needs?

\section{Learning and Development}

Student learning and development gives attention to knowledge acquisition regarding diverse groups and cultures as well as cognitive and social development (Williams et al., 2005). Additionally, the student learning and development category addresses racial and ethnic identity development, the development of a national identity, and connections between the study abroad experience and academic major/minor.

Kasravi (2009) found that academic concerns were a priority for both students who studied abroad and those who opted not to participate. Students who did not study abroad indicated that a 
main barrier was the fact that courses abroad did not fit into their academic program and the difficulty in getting classes approved (Kasravi, 2009). Similarly, Van Der Meid found that the primary reason that Asian American students did not go abroad was that study abroad did not seem appropriate for their academic programs (2003). Latino/a students in McClure et al.'s study expressed concern that study abroad would delay graduation, which would then lead to increased financial pressures (2010). While students who did study abroad overcame these academic barriers by changing majors, adding a second major, or delaying graduation (Kasravi, 2009), it seems that better integration of study abroad into the curriculum and deliberate connections between learning abroad and on the home campus would facilitate and enhance the study abroad experience for all students. Study abroad is often marketed as an opportunity for students to explore new cultures; students of color may not find that argument appealing, as many already successfully operate in multiple cultural contexts within the U.S. (Jackson, 2006). A strong connection to their academic program and an opportunity to explore their major discipline from a new perspective might be more attractive.

Study abroad may have a positive impact on racial and ethnic identity development for students of color (Day-Vines, Barker, \& Exum, 1998; Doan, 2002; Jackson, 2006; Landau \& Moore, 2001; $\mathrm{Ng}$, 2003). Additionally, students may develop a stronger national identity. While some challenges related to climate abroad were discussed in a previous section, students of color may be surprised to discover that they are seen first as Americans by members of the host country rather than a person of color. Jackson (2006) noted that several of her participants began to discover an American national identity as they explored their African American identities; "the participants had previously expressed ambivalence about claiming American as part of their identities because of issues of racism in the U.S....Therefore, being seen as American first and African American second was amazing to them" (p. 148). Similar revelations occur for African American sojourners, as described below by two travel writers:

On my first venture to Europe - France, Germany, and Switzerland -- I saw no gaping mouths, no fish-faced looks, no double takes. I was astonished to discover that most of the Europeans I encountered viewed me first and foremost as an American. Not a black person. Not even a black American. As far as they were concerned, any differences between us were due to my American culture, not my color. I had never experienced that perception before certainly not in my own country, where my color is the first thing that people notice about me (and I of them) (Grenier, 1997, p. 202).

Traveling, they taught me, means giving up personal ego and nationalistic arrogance. My hosts referred to me as the "American." I had to accept the fact that, as quiet as it's kept here in my own country, I am an American. Yet nothing in my experience had allowed me to think of myself in that way. At best I was a hyphenate: an African American. Some derivative of the "real" thing. In London I was a different type of "other", standing outside another norm. I am an American (Lazard, 1997, p. 222). 


\section{Inclusive Excellence Scorecard: Indicators for Learning and Development}

The learning and development area of the scorecard is the least understood within study abroad. As institutions increasingly focus on developing learning outcomes and means for assessment, the experiences and outcomes of students of color should also be considered. To examine the learning and development of study abroad participants, institutions may consider opportunities for reflection, comparisons of learning outcomes, and self-reported skills development and personal growth (see Table 5). Are all students offered structured or unstructured opportunities to reflect on race and ethnicity while abroad and upon the return to campus? Are there direct connections between academic majors and study abroad opportunities, and do students in all majors have the opportunity to study abroad? Institutions are increasingly asked to assess learning outcomes for study abroad participants, and should consider race and ethnicity of students as a variable to determine whether there are differences in outcomes. What do students themselves report gaining from the study abroad experience? As discussed in the previous section, empirical studies suggest that U.S. students of color may experience both racial/ethnic and national identity development as a result of participation in study abroad. More research is needed regarding learning outcomes of study abroad to fully understand the potential for growth and development for all students, and to better understand the outcomes for students of color.

\section{Conclusion}

Dialogue regarding the participation of students of color in study abroad must move beyond a focus solely on numbers, access, and deficits of students of color. The inclusive excellence scorecard (Tables 2-5) can be used as a tool for institutions to examine the participation and success of students of color in study abroad through the interconnected areas of access and equity, climate, diversity in the curriculum, and learning and development. It is crucial that institutions start efforts to impact underrepresentation by first considering conditions on their own campuses. These selfassessments can then be shared to contribute to the larger body of knowledge regarding students of color and study abroad. Not all of the indicators will be relevant or appropriate to every institution/organization. This scorecard was developed from the author's experience working in a U.S. university setting. While many of these indicators can be useful for program providers and host universities, additional indicators can be developed that are more applicable to the work and spheres of influence of these types of institutions.

Additional research is needed to address the experiences of students of color abroad, as well as similarities and differences among different racial and ethnic groups and subgroups. While the focus of this scorecard is limited to students of color, it is also important to recognize that multiple identities play a part in the study abroad experience, including gender identity, socioeconomic status, generational status in the U.S. and in college, and sexual orientation, to name a few. There are also many other underrepresented groups in study abroad, and the concept of inclusive excellence can be utilized to examine the participation of these groups as well. 
Inclusive excellence requires an examination of the experiences of students of color both individually and collectively (Tuitt, 2009). Until institutions have a clear understanding of the experiences, challenges, and opportunities on their own campuses and study abroad programs, they cannot effectively create change to better serve students of color in the pre-departure, in-country, and reentry phases of study abroad. In order to be successful, these efforts must be coordinated as part of larger institutional efforts toward creating an inclusive campus.

Inclusive excellence has much to offer the field of study abroad, and has the potential to enhance study abroad participation - and quality of experience - for students of color. This, along with a deliberate focus on diversity in the curriculum, may have a positive impact on all students who are provided with opportunities to not only learn about the culture of a new country, but to also explore their own identities and cultural contexts related to race and ethnicity. While students of color who do not study abroad miss out on individual opportunities for growth, underrepresentation also impacts institutions, industry, our country, and communities abroad, who all fail to benefit from the contributions of students of color.

\section{References}

Allen, W.R., Epps, E.G., Guillory, E.A., Suh, S.A., Bounous-Hammarth, M., \& Stassen, M.L.A. (2002). Outsiders within: Race, gender, and faculty status in U.S. higher education. In W.A. Smith, P.G. Altbach, \& K. Lomotey (Eds.), The racial crisis in American higher education: Continuing challenges for the twenty-first century (pp. 189-220). Albany, NY: SUNY Press.

Anderson, L.C. \& Murray, C.S. (2005). Advising principles and strategies. In J.L. Brockington, W.W. Hoffa, and P.C. Martin (Eds.), NAFSA's guide to education abroad for advisers and administrators (pp. 173-191). Washington, D.C.: NAFSA: Association of International Educators.

Bailey Shea, C. (2009). Issues that affect American college students' participation in study abroad (Doctoral dissertation). Retrieved from Proquest Dissertations and Theses. (Publication No. AAT 3395372).

Bauman, G.L., Bustillos, L.T., Bensimon, E.M., Brown II, M.C., \& Bartee, R.D. (2005). Achieving equitable educational outcomes with all students: The institution's roles and responsibilities.

Washington, D.C.: Association of American Colleges and Universities.

Bolen, M.C. (Ed.). (2007). A Guide to Outcomes Assessment in Education Abroad. Carlisle, PA: Forum on Education Abroad.

Carter, H.M. (1991). Minority access to international education. In Council on International Educational Exchange, Black students and overseas programs: Broadening the base of participation (pp. 9-20). Papers and speeches presented at the $43^{\text {rd }}$ CIEE International Conference on Educational Exchange, Charleston, SC, November 7-9, 1990. Retrieved from http://www.eric.ed.gov/PDFS/ED340323.pdf

Chesler, M., Lewis, A., \& Crowfoot, J. (2005). Challenging Racism in Higher Education. Lanham, MD: Rowman \& Littlefield Publishres, Inc.

Cole, J.B. (1991). Opening address of the $43^{\text {rd }}$ international conference on educational exchange. In Council on International Educational Exchange, Black students and overseas programs: 
Broadening the base of participation (pp.1-8). Papers and speeches presented at the $43^{\text {rd }} \mathrm{CIEE}$ International Conference on Educational Exchange, Charleston, SC, November 7-9, 1990. Retrieved from http://www.eric.ed.gov/PDFS/ED340323.pdf

Comp, D. (2007). What we know about diversity in education abroad: State of the research. In C.A. Herrin, S. Dadzie, \& S.A. MacDonald (Eds.), Proceedings for the Colloquium on Diversity in Education Abroad: How to Change the Picture (pp.48-52). Washington, D.C.: Academy for Educational Development.

Comp, D. (2008). U.S. heritage-seeking students discover minority communities in Western Europe. Journal of Studies in International Education 12 (29-37).

Day-Vines, N., Barker, J.M., \& Exum, H.A. (1998, September). Impact of diasporic travel on ethnic identity development of African American college students. College Student Journal, 32(3), 463-471.

Doan, T.M. (2002). Asian American students: Study abroad participation, perspectives and experiences (Master's thesis, University of Minnesota). Retrieved from http://oldlac.gps.umn.edu/ci/resources/planBPaper/complete\%20paper.pdf

Evans, S.Y. (2009). African American women scholars and international research: Dr. Anna Julia Cooper's legacy of study abroad. Frontiers: The Interdisciplinary Journal of Study Abroad, 18, 77100.

Ganz, M.A. (1991). The Spelman experience: Encouraging and supporting minority students abroad. In Council on International Educational Exchange, Black students and overseas programs: Broadening the base of participation (pp.43-55). Papers and speeches presented the $43^{\text {rd }}$ CIEE International Conference on Educational Exchange, Charleston, SC, November 7-9, 1990. Retrieved from http://www.eric.ed.gov/PDFS/ED340323.pdf

Goodwin, C.D. \& Nacht, M. (1988). Abroad and beyond: Patterns in American overseas education. New York, NY: Cambridge University Press.

Grenier, D. (1997). Homegirl on the range. In E. Lee (Ed.), Go girl! The Black woman's book of travel and adventure (pp. 199-204). Portland, OR: Eighth Mountain Press.

Guerrero, E. (2006). The road less traveled: Latinalo students and the impact of studying abroad. (Doctoral Dissertation, University of Californa, Los Angeles, California). Retrieved from http://gradworks.umi.com/32/49/3249418.html

Harper, S.R. \& Quaye, S.J. (2009). Beyond sameness, with engagement and outcomes for all: An introduction. In S.R. Harper and S.J. Quaye (Eds), Student engagement in higher education: Theoretical perspectives and practical approaches for diverse populations (pp. 1-15). New York, NY: Routledge.

Hoffa, W.W. \& DePaul, S.C. (2010). Introduction. In W.W. Hoffa \& S.C. DePaul (Eds.). A history of U.S. study abroad: 1965-Present (pp. 1-13). Frontiers: The Interdisciplinary Journal of Study Abroad: Carlisle, PA.

Hurtado, S. (2002). Creating a climate of inclusion: Understanding Latina/o college students. In W.A. Smith, P.G. Altbach, \& K. Lomotey (Eds.), The racial crisis in American higher education: Continuing challenges for the twenty-first century (pp. 121-135). Albany, NY: SUNY Press.

Institute of International Education (2012). Open doors 2012 report on international educational exchange: Profile of U.S. study abroad students, 2000/2001-2010/11. Retrieved from the Institute 
of International Education website: http://opendoors.iienetwork.org/

Jackson, M.J. (2005, Fall). Breaking the barriers to overseas study for students of color and minorities. IIE Networker, 16-18. Retrieved from Institute of International Education website: http://www.iienetwork.org

Jackson, M.J. (2006). Traveling shoes: Study abroad experiences of African American students participating in California State University international programs (Doctoral dissertation). Retrieved from ProQuest Dissertations and Theses database. (AAT 3227519).

Jefferson, K.M. (1997). Genesis of the traveling spirit. In E. Lee (Ed.), Go girl! The Black woman's book of travel and adventure (pp. 269-274). Portland, OR: Eighth Mountain Press.

Johnson, S., Rinehart, N., \& Van Cleve, L. (2005). Program designs and strategies. In J.L. Brockington, W.W. Hoffa, and P.C. Martin (Eds.), NAFSA's guide to education abroad for advisers and administrators (pp. 345-371). Washington, D.C.: NAFSA: Association of International Educators.

Kasravi, J. (2009). Factors influencing the decision to study abroad for students of color: Moving beyond the barriers (Doctoral dissertation, University of Minnesota). Retrieved from http://purl.umn.edu/55058

Kuh, G.D. (2009). Afterword. In S.R. Harper and S.J. Quaye (Eds), Student engagement in higher education: Theoretical perspectives and practical approaches for diverse populations (pp. 313-18). New York, NY: Routledge.

Landau, J. \& Moore, D.C. (2001). Towards reconciliation in the motherland: Race, class, nationality, gender, and the complexities of American student presence at the University of Ghana, Legon. Frontiers: The Interdisciplinary Journal of Study Abroad, 7, 25-58. Retrieved from http://www.frontiersjournal.com/issues/vol7/

Lazard, D. (1997). Finding myself in the world. In E. Lee (Ed.), Go girl! The Black woman's book of travel and adventure (pp. 221-225). Portland, OR: Eighth Mountain Press.

Lebold, C.J., Henry, A., Houston, P., Jackson, M., Scheibe, M., \& Van Der Meid, S. (2005). Reaching underrepresented constituencies. In J.L. Brockington, W.W. Hoffa, and P.C. Martin (Eds.), NAFSA's guide to education abroad for advisors and administrators (pp. 207-238). Washington, D.C.: NAFSA: Association of International Educators.

Lewis, H. (2009). A student's guide to being happy in Argentina. Paoli, PA: The Elevator Group. McClure, K.R., Szelenyi, K., Niehaus, E., Anderson, A.A., \& Reed, J. (2010). "We just don't have the possibility yet": U.S. Latina/o narratives on study abroad. Journal of Student Affairs Research and Practice, 47(3), 367-386. doi: 10.2202/1949-6605.6506

Milem, J.F., Chang, M.J., \& Antonio, A.L. (2005). Making diversity work on campus: A researchbased perspective. Washington, D.C.: Association of American Colleges and Universities.

National Center for Education Statistics. (2011). Total fall enrollment in degree-granting institutions, by level of student, sex, attendance status, and race/ethnicity: Selected years, 1976 through 2010. Retrieved from http://nces.ed.gov

$\mathrm{Ng}, \mathrm{H}$. (2003). Sojourner's truth: Intergenerational conflict and racial identity attitudes among second generation Asian American participants in college study abroad programs in Asia (Psy.D. Dissertation, Wright Institute). Available from ProQuest Dissertation and Theses database. (Publication No. AAT 3118441) 
Norfles, N. (2003, January). Toward equal and equitable access: Obstacles and opportunities in international education. Paper presented at the Global Challenges and U.S. Higher Education Research Conference, Duke University, Durham, North Carolina. Retrieved from http://ducis.jhfc.duke.edu/archives/globalchallenges/pdf/norfles_paper.pdf

Obama, M. (2011, January 19). First Lady Michelle Obama's 100,000 strong China study abroad initiative [video recording]. Retrieved from http://vimeo.com/18991021

Penn, E.B. \& Tanner, J. (2009). Black students and international education: An assessment. Journal of Black Studies 40, 266-282. doi: 10.1177/0021934707311128

Picard, E., Bernardino, F., \& Ehigiator, K. (2009). Global citizenship for all: Low minority participation in study abroad - seeking strategies for success. In R. Lewis (Ed.), The handbook of practice and research in study abroad: Higher education and the quest for global citizenship (pp. 321-345). New York, NY: Routledge.

Raby, R. (2006, Fall). Community college study abroad: Making study abroad accessible to all students. IIE Networker, 39-40.

Redden, E. (2010, July 13). Academic outcomes of study abroad. Inside Higher Ed. Retrieved from www.insidehighered.com

Salisbury, M.H., Umbach, P.D., Paulsen, M.B., \& Pascarella, E.T. (2009). Going global: Understanding the choice process of the intent to study abroad. Research in Higher Education 50, 119-143. Doi: 10.1007/s11162-008-9111-x.

Salisbury, M., Paulsen, M., \& Pascarella, E. (2011). Why do All the Study Abroad Students Look Alike? Applying an Integrated Student Choice Model to Explore Differences in the Factors that Influence White and Minority Students' Intent to Study Abroad. Research in Higher Education, 52(2), 123-150. doi:10.1007/s11162-010-9191-2

Stallman, E., Woodruff, E., Kasravi, J., \& Comp, D. (2010). The diversification of the student profile. In W. W. Hoffa and S.C. DePaul (Eds.), A history of U.S. study abroad: 1965-present (pp.115-160). A special publication of Frontiers: The Interdisciplinary Journal of Study Abroad. Lancaster, PA: Frontiers.

Stearns, P.N. (2009). Educating global citizens in colleges and universities: Challenges and opportunities. New York, NY: Routledge.

Sutton, R. \& Rubin, D. (n.d.). Selected GLOSSARI research findings pertaining to student diversity and education abroad. Retrieved from http://glossari.uga.edu

Talburt, S., \& Stewart, M.A. (1999). What's the subject of study abroad? Race, gender, and "living culture." The Modern Language Journal 83, 163-175.

Tuitt, F. (2009). Summary. In M.F. Howard-Hamilton, C.L. Morelon-Quainoo, S.D. Johnson, R. Winkle-Wagner, and L. Santiague (Eds.), Standing on the outside looking in: Underrepresented students' experiences in advanced-degree programs (pp. 203-226). Sterling, VA: Stylus.

U.S. Department of Education (2011). Federal TRIO programs. Retrieved from the U.S. Department of Education website: http:/www2.ed.gov/about/offices/list/ope/trio/index.html

Van Der Meid, J.S. (2003). Asian Americans: Factors influencing the decision to study abroad. Frontiers: The Interdisciplinary Journal of Study Abroad, 9, 71-110. Retrieved from http://www.frontiersjournal.com/issues/vol9/

Williams, D.A., Berger, J.B., \& McClendon, S.A. (2005). Toward a model of inclusive excellence and 
change in postsecondary institutions. Washington, D.C.: Association of American Colleges and Universities.

Table 1 Total U.S. Fall enrollment in degree-granting post-secondary institutions and annual study abroad participation, percentage distribution by race and ethnicity

\begin{tabular}{|c|c|c|c|c|c|c|c|c|c|c|c|c|}
\hline $\begin{array}{l}\text { Race/ } \\
\text { Ethnicity }\end{array}$ & $\begin{array}{l}\text { U.S. } \\
2005\end{array}$ & $\begin{array}{l}\text { Study } \\
\text { Abroad } \\
2005 / 06\end{array}$ & $\begin{array}{l}\text { U.S. } \\
2006\end{array}$ & $\begin{array}{l}\text { Study } \\
\text { Abroad } \\
2006 / 07\end{array}$ & $\begin{array}{l}\text { U.S. } \\
2007\end{array}$ & $\begin{array}{l}\text { Study } \\
\text { Abroad } \\
2007 / 08\end{array}$ & $\begin{array}{l}\text { U.S. } \\
2008\end{array}$ & $\begin{array}{l}\text { Study } \\
\text { Abroad } \\
2008 / 09\end{array}$ & $\begin{array}{l}\text { U.S. } \\
2009\end{array}$ & $\begin{array}{l}\text { Study } \\
\text { Abroad } \\
2009 / 10\end{array}$ & $\begin{array}{l}\text { U.S. } \\
2010\end{array}$ & $\begin{array}{l}\text { Study } \\
\text { Abroad } \\
2010 / 11\end{array}$ \\
\hline White & 65.7 & 83 & 65.2 & 81.9 & 64.4 & 81.8 & 63.3 & 80.5 & 62.3 & 78.7 & 60.5 & 77.8 \\
\hline $\begin{array}{l}\text { Asian/ } \\
\text { Pacific } \\
\text { Islander }\end{array}$ & 6.5 & 6.3 & 6.6 & 6.7 & 6.7 & 6.6 & 6.8 & 7.3 & 6.5 & 7.9 & 6.1 & 7.9 \\
\hline $\begin{array}{l}\text { Hispanic or } \\
\text { Latino/a }\end{array}$ & 10.8 & 5.4 & 11.1 & 6.0 & 11.4 & 5.9 & 11.9 & 6.0 & 12.5 & 6.4 & 13 & 6.9 \\
\hline $\begin{array}{l}\text { Black or } \\
\text { African } \\
\text { American }\end{array}$ & 12.7 & 3.5 & 12.8 & 3.8 & 13.1 & 4 & 13.5 & 4.2 & 14.3 & 4.7 & 14.5 & 4.8 \\
\hline Multiracial & * & 1.2 & * & 1.2 & * & 1.2 & * & 1.6 & * & 1.9 & 1.5 & 2.1 \\
\hline $\begin{array}{l}\text { American } \\
\text { Indian/ } \\
\text { Alaska } \\
\text { Native }\end{array}$ & 1 & 0.6 & 1 & 0.5 & 1 & 0.5 & 1 & 0.5 & 1 & 0.5 & 0.9 & 0.5 \\
\hline
\end{tabular}

Note. *NCES data did not include a multiracial category until 2010. U.S. enrollment in post-secondary institution data is from National Center for Education Statistics (2011); study abroad data is from Institute of International Education (2012). 
Table 2 Inclusive Excellence Scorecard: Access and Equity in Study Abroad

\begin{tabular}{|c|c|c|}
\hline $\begin{array}{l}\text { Inclusive } \\
\text { Area }\end{array}$ & Definition & Sample Indicators \\
\hline Access and Equity & $\begin{array}{l}\text { The compositional } \\
\text { number and } \\
\text { success levels of } \\
\text { students of color in } \\
\text { study abroad }\end{array}$ & $\begin{array}{l}\text { What is the profile of students of color on the home } \\
\text { campus? } \\
\text { How do the race/ethnicity of study abroad participants } \\
\text { compare to the race/ethnicity of the overall student } \\
\text { population? } \\
\text { Are certain majors more likely to study abroad? Are } \\
\text { students of color equally represented in these majors? } \\
\text { How do students hear about study abroad? Are there } \\
\text { different patterns according to race/ethnicity? } \\
\text { Are students aware of available scholarships for study } \\
\text { abroad and how to use financial aid? If students with } \\
\text { financial need are not applying for scholarships, why not? } \\
\text { What do applicants identify as goals and potential } \\
\text { challenges for their study abroad experiences? Do these } \\
\text { differ by race/ethnicity? } \\
\text { What do students of color who opt not to study abroad } \\
\text { say were the factors that led to this decision? } \\
\text { How does the race/ethnicity of students who apply for } \\
\text { study abroad but withdraw or return early compare to that } \\
\text { of the overall study abroad population? What factors } \\
\text { influence these decisions? } \\
\text { How does the race/ethnicity of students who study } \\
\text { abroad multiple times, or opt to extend for a year, } \\
\text { compare to that of the overall study abroad population? } \\
\text { Does the impact of study abroad on home campus GPA } \\
\text { vary by race/ethnicity? } \\
\text { Does study abroad participation impact graduation rates? } \\
\text { If so, do these vary by race/ethnicity? }\end{array}$ \\
\hline
\end{tabular}

Note. Inclusive Excellence Scorecard adapted from Williams, Berger, \& McClendon, 2005, p.21. 
Table 3 Inclusive Excellence Scorecard: Campus Climate in Study Abroad

\begin{tabular}{|c|c|c|}
\hline $\begin{array}{l}\text { Inclusive Excellence } \\
\text { Area }\end{array}$ & Definition & Sample Indicators \\
\hline Campus Climate & $\begin{array}{l}\text { The development } \\
\text { of a psychological } \\
\text { and behavioral } \\
\text { climate supportive } \\
\text { of all students, both } \\
\text { on the home } \\
\text { campus and on the } \\
\text { study abroad } \\
\text { program. }\end{array}$ & $\begin{array}{l}\text { What is the race/ethnicity of staff, including student workers, } \\
\text { in the study abroad office? } \\
\text { What is the race/ethnicity of faculty at the home institution } \\
\text { who lead study abroad programs? } \\
\text { What is the race/ethnicity of staff, faculty, and students at } \\
\text { host institutions? } \\
\text { Are students of color represented in marketing (print and } \\
\text { web) materials? } \\
\text { Does the home institution's mission statement mention study } \\
\text { abroad? } \\
\text { Does the study abroad office's mission statement mention } \\
\text { diversity? } \\
\text { What types of outreach efforts exist to encourage students of } \\
\text { color to study abroad? } \\
\text { Are faculty/staff/administrators supportive of study abroad? } \\
\text { Can they articulate its value to students? Pay particular } \\
\text { attention to those who act as mentors for students of color on } \\
\text { campus. } \\
\text { What are the findings of campus climate surveys on the } \\
\text { home campus? How might these issues impact study abroad } \\
\text { participation? } \\
\text { What types of opportunities for development related to } \\
\text { diversity issues exist for staff and faculty on the home } \\
\text { campus? } \\
\text { Do formal or informal mentoring opportunities between } \\
\text { students exist? } \\
\text { Do host country faculty and staff have experience working } \\
\text { with students of color? What development opportunities exist } \\
\text { regarding diversity issues? } \\
\text { Do host families have experience working with students of } \\
\text { color? Do programs select or reject families based on their } \\
\text { attitudes towards diverse students? } \\
\text { Where are students of color choosing to study abroad? Are } \\
\text { there patterns in terms of program or country selection? } \\
\text { What do students report about how their racial/ethnic } \\
\text { identities impacted their study abroad experience? } \\
\text { Do students face discrimination abroad? How do they } \\
\text { perceive the climate on the host campus/in the host country? } \\
\text { What do students of color report about their relationships with } \\
\text { other international/study abroad students? } \\
\text { What challenges do study abroad participants report? Do } \\
\text { these vary by race/ethnicity? } \\
\text { What advice do students of color provide for future } \\
\text { participants of color? }\end{array}$ \\
\hline
\end{tabular}

Note. Inclusive Excellence Scorecard adapted from Williams, Berger, \& McClendon, 2005, p.21. 
Table 4 Inclusive Excellence Scorecard: Diversity in the Curriculum in Study Abroad

\begin{tabular}{|l|l|l|}
\hline $\begin{array}{l}\text { Inclusive Excellence } \\
\text { Area }\end{array}$ & Definition & Sample Indicators \\
\hline $\begin{array}{l}\text { Diversity in the Formal } \\
\text { and Informal Curriculum }\end{array}$ & $\begin{array}{l}\text { Diversity content in } \\
\text { study abroad } \\
\text { programs, } \\
\text { including advising } \\
\text { materials, } \\
\text { information } \\
\text { sessions, } \\
\text { orientations, } \\
\text { classes, } \\
\text { excursions, and } \\
\text { social activities at and } \\
\text { home and abroad. } \\
\text { Do impact of race/ethnicity on the student's study abroad } \\
\text { experience? } \\
\text { Do orientations and classes abroad include discussions } \\
\text { of race and ethnicity? } \\
\text { Is the historical participation by communities of color in } \\
\text { study abroad (or other international arenas) highlighted? } \\
\text { Are the study abroad programs offered of interest to } \\
\text { students of color at the home institution in terms of } \\
\text { location, academic content, and length? } \\
\text { Are the contributions of persons/communities of color } \\
\text { discussed in classes abroad? In cultural excursions? }\end{array}$ \\
\hline
\end{tabular}

Note. Inclusive Excellence Scorecard adapted from Williams, Berger, \& McClendon, 2005, p.21.

Table 5 Inclusive Excellence Scorecard: Learning and Development in Study Abroad

\begin{tabular}{|l|l|l|}
\hline $\begin{array}{l}\text { Inclusive Excellence } \\
\text { Area }\end{array}$ & Definition & Sample Indicators \\
\hline Learning and Development & $\begin{array}{l}\text { The acquisition of } \\
\text { content knowledge } \\
\text { about diverse groups } \\
\text { and cultures, } \\
\text { connections with } \\
\text { academic learning } \\
\text { on campus, and } \\
\text { racial, ethnic, and } \\
\text { national identity } \\
\text { development }\end{array}$ & $\begin{array}{l}\text { Are there direct connections between academic majors and } \\
\text { to campus? }\end{array}$ \\
& $\begin{array}{l}\text { Are there differences in outcomes of assessment data by } \\
\text { racelethnicity? }\end{array}$ \\
& $\begin{array}{l}\text { What do your students report gaining from study abroad? Are } \\
\text { there differences by race/ethnicity? } \\
\text { Do existing programs support students' motivations and goals } \\
\text { for study abroad? } \\
\text { Do students indicate an impact on identity development as a } \\
\text { result of study abroad? }\end{array}$ \\
\hline
\end{tabular}

Note. Inclusive Excellence Scorecard adapted from Williams, Berger, \& McClendon, 2005, p.21. 